Please do not remove this page

RMIT

UNIVERSITY

\title{
Variations in the rate at which students cross the boundaries between Australian vocational and higher education
}

Moodie, Gavin

https://researchrepository.rmit.edu.au/esploro/outputs/9921858247301341/filesAndLinks?institution=61RMIT_INST\&index=null

Moodie, G. (2012). Variations in the rate at which students cross the boundaries between Australian vocational and higher education. Australian Educational Researcher, 39(2), 143-158.

https://doi.org/10.1007/s13384-012-0054-z

Document Version: Accepted Manuscript

Published Version: https://doi.org/10.1007/s13384-012-0054-z

Repository homepage: https://researchrepository.rmit.edu.au

(C) The Australian Association for Research in Education, Inc. 2012

Downloaded On 2023/04/26 12:54:30 +1000

Please do not remove this page 
Thank you for downloading this document from the RMIT Research Repository.

The RMIT Research Repository is an open access database showcasing the research outputs of RMIT University researchers.

RMIT Research Repository: http://researchbank.rmit.edu.au/

\section{Citation:}

Moodie, G 2012, 'Variations in the rate at which students cross the boundaries between Australian vocational and higher education', Australian Educational Researcher , vol. 39, no. 2, pp. 143-158.

See this record in the RMIT Research Repository at: http://researchbank.rmit.edu.au/view/rmit:21156

Version: Accepted Manuscript

Copyright Statement: (C) The Australian Association for Research in Education, Inc. 2012

Link to Published Version:

http://dx.doi.org/10.1007/s13384-012-0054-z

\section{PLEASE DO NOT REMOVE THIS PAGE}


Moodie, Gavin (2012) Variations in the rate at which students cross the boundaries between Australian vocational and higher education, Australian Educational Researcher, volume 39, issue 2, pages 143-158, DOI 10.1007/s13384-012-0054-z.

\title{
Variations in the rate at which students cross the boundaries between Australian vocational and higher education
}

\author{
Gavin Moodie, RMIT
}

\begin{abstract}
This paper considers the rate at which students are crossing the boundaries between Australian vocational and higher education. It finds that public universities admit a higher proportion of students on the basis of a vocational education qualification than do private colleges and that private colleges broadly do not admit a higher proportion of students from a low socioeconomic status background than public universities do.

Vocational education transfers are most important in the higher education fields of nursing (22\% of commencing students), education (13\%) and information technology (12\%). Upward transfers are least important in the natural and physical sciences (3.5\%) and engineering and related technologies (6\%). Some $17 \%$ of commencing students are from a low socioeconomic status background, but nursing (24\%) and education (22\%) provide more opportunities for students from a low socioeconomic status background. Conversely, fewer opportunities are provided in architecture and building (12\%) and the creative arts (14\%).
\end{abstract}

There is considerable variation in the proportion of students that higher education institutions admit on the basis of vocational qualifications, even in a relatively homogeneous field such as nursing. Some of this apparent variation may be explained by different treatment of admissions data, but much remains unexplained.

\section{Keywords}

student transfer, pathways, vocational education, higher education, nursing

\section{Introduction}

The divide between Australian vocational and higher education had reached its nadir when Australian tertiary education was last considered extensively in the pages of the Australian Educational Researcher, in 2007. The guest editor of the journal's special edition on post compulsory education and changing practices argued that 'there is an urgent need for research to better identify how far (if at all) the boundaries between education levels, sectors and providers are being broken down through the formation of enhanced and flexible credentialling and qualifications pathways and changes to young people's lives, study and work choices' (Crump 2007, p. 2). He further argued that 'while qualifications policy is pushing further and higher education together, broader policies related to the resourcing of education could be forcing TAFE and University collaboration apart' (Crump 2007, p. 2). 
Since then the Australian Government's (Commonwealth of Australia 2009) major statement of policy on higher education stated:

To enhance this interconnection we need an education system that is less fragmented and easier for students to navigate. It should be straight forward (sic) for students to enter post-school education and move between vocational and higher education as appropriate to enhance their skills and qualifications. (p. 43)

This policy has been widely accepted within vocational and higher education and seems to have bipartisan support. The policy statement followed a review of Australian higher education (Bradley 2008, p. 180) which concluded 'that although distinct sectors [of vocational and higher education] are important, it is also vital that that [sic] there should be better connections across tertiary education and training to meet economic and social needs which are dynamic and not readily defined by sectoral boundaries'. The review went on to consider how to improve pathways for students from vocational to higher education (p. 192).

Student pathways within and between sectors of tertiary education are an important characteristic of the processes or internal dynamics that make it sensible to talk about a system, rather than sectors or institutions operating in isolation from each other. Student pathways reflect the nature of a tertiary education system and, depending on that nature, can be an important indicator of the system's success. Some countries, most typically in Germany and other parts of northern continental Europe, tend to coordinate their market economies with their social partners: governments at national and regional levels, business and labour (Hall and Soskice 2001). These countries typically meet the different needs of the economy and of students, employers and society generally, by structuring sectors and institutions to serve specific needs. These societies most commonly establish vocational institutes to specialise in developing skills for employment, and higher education institutions to provide academic education and education for the high-status, high-paying occupations. These countries sharply differentiate and separate vocational education from higher education in organisation, curriculum and student groups. In these systems, students enter either a vocational or an academic education track in the senior years of secondary education and proceed along that track to either a vocational or higher education tertiary institution, and thence to an occupation specific to their vocational or higher education track. These systems therefore are often known as 'tracked' systems. While vocational and higher education students are placed on quite separate post-compulsory education tracks, the coordinated market economy matches graduates and job vacancies for most graduates. These systems have a sufficiently stable labour market to encourage enterprises and employees to invest heavily in vocationally specific skills (Moodie 2008, pp. 4-5; 138-9).

Other countries, typically the UK and the US, have rather more fluid, liberal market economies which rely more on the market to sort and match graduates and employment. Liberal market economies (Hall and Soskice 2001) place more responsibility on students and workers to fit themselves to the needs of current and prospective employers. Workers facing short job tenures and fluid and unpredictable labour markets therefore prefer general vocational education, since career success depends on acquiring the general skills that can be used in many different firms. Greater mobility between vocational and higher education gives students more flexibility to match their education with employment opportunities as they arise (Moodie 2008 pp. 4-5; 138-9).

Performance in the highly differentiated, tracked systems of tertiary education in coordinated market economies is optimised when there is a good match of students, sectors and society's needs. In these systems, large numbers of students transferring between vocational and higher 
education, and indeed between programs within a sector, indicate a failure of the system to place students on the appropriate track initially, and a consequent loss of heavy investment in vocationally specific education. But in generalist systems in liberal market economies, high rates of student transfer indicate their success in providing students with the flexibility to change their education and careers in response to economic and social changes and in response to changes in their life circumstances (Moodie 2008, pp. 4-5; 138-9).

Australia is in the anomalous position of having a relatively differentiated system of tertiary education within a liberal market economy (Wheelahan and Moodie 2005). It is therefore moot whether high rates of student transfer between Australian vocational and higher education would indicate a failure of the relatively differentiated system of tertiary education to place students in the most suitable sector initially, or whether a high rate of transfer indicate the success of the system and its students to, nonetheless, respond to the needs of Australia's liberal market economy. It seems from the Australian Government's policy on higher education that it is moving to a more generalist system of tertiary education in which a high rate of student transfer is considered an indication of the system's success.

This paper considers one pathway between vocational and higher education, the transfer of students from vocational to higher education. In the US the upward transfer of students from community colleges to four-year colleges and universities is mostly thought to reflect the success of community colleges in fulfilling an important part of their role. Thus, a recent report (Smith and Miller 2009) on promising practices promoting transfer among low income and first generation students was a detailed study of six exemplary community colleges in Texas. Previous US studies have sought to identify factors that explain differences in transfer rates among community colleges (Wassmer, Moore and Shulock 2003, p. 21), the features of community college education that result in some transfer students having lower grade point averages than students admitted directly into a university (Carlan and Byxbe 2000), what community colleges may do to increase upward transfer (Striplin 1999; Dougherty 1992) and how community colleges sustain their transfer function in the face of pressures to diversify their functions, such as by increasing their vocational emphasis (Shaw and London 1995).

Transfer from vocational to higher education emerged as an issue more recently in the UK, and hence there is less literature on this issue. But UK research is more likely to accept Gelin's (1999, p. 11) argument for British Columbia that 'Effective transfer is a function of both sending and receiving institutional policies, practices, and culture. Using transfer rates to measure the effectiveness of the sending institution leaves out one half of the equation' (Hefce 2006; Hoelscher et al. 2008). This is reinforced by the transfer from vocational to higher education often being within the same mixed sector institution (Parry 2003; Gallacher 2003), which in turn has stimulated UK interest in mixed sector institutions (Garrod and Macfarlane 2009; Bathmaker et al. 2008).

The Australian literature on upward student transfer is more likely to be the converse of the US literature, concentrating on receiving rather than sending institutions (Moodie 2005, 2008; Curtis 2006; Wheelahan 2009). This is partly because public vocational institutions have had no formal role in transferring students to higher education since at least 1987, because it is thought this may divert them from training workers for employment (Stevenson 2007, p. 20) and because some feel that such a role is demeaning (White 2009).

This paper follows the Australian tradition of considering higher education institutions' role in upward student transfer. It first considers transfer rates by different types of higher education institution, for the first time in the author's knowledge, reporting rates for private higher education institutions and Technical and Further Education (TAFE) institutes. It then considers transfer rates by field of education and concludes by examining transfer rates for 
nursing in some detail. Nursing is interesting because higher education institutions admit an unusually high proportion of bachelor of nursing students on the basis of vocational education qualifications; this may inform other fields.

The paper reports an examination of a special higher education statistical report from the Department of Education, Employment and Workplace Relations (Doherty 2009) on students admitted in 2008 to higher education institutions on the basis of a vocational education and training award program, by higher education institution, field of education and socioeconomic status. Readers should note that the Australian higher education data on students by basis of admission are not very accurate, since they are collected differently (and indifferently) by many institutions. Moodie (2005 pp. 20-1) describes the problems with the data in detail, and specific issues where relevant are noted below.

\section{Variations by institution type}

As has been observed before (Moodie 2005; 2007), universities of different types admit distinctly different proportions of undergraduate students on the basis of vocational education qualifications. The table below groups universities as follows: members of the Australian Technology Network - universities which were institutes of technology for much of their history, and the similar Swinburne University of Technology; the new generation of universities established as universities after 1988; those established from the mid 1960s to the mid 1970s; universities which are mostly based in rural areas; and the members of the Group of Eight universities, established over 50 years ago in the mainland capital cities, and which have high research expenditure. (The members of each university type are listed in Table 7, the last in this paper.)

Also shown are the proportions of commencing undergraduate students that institutions admit from a low socioeconomic status background. Again, this has been reported before (Wheelahan 2009). There is not a strong relation between the proportion of undergraduates a university admits on the basis of a vocational education qualification and the proportion of undergraduates it admits from a low socioeconomic status background. Subsequent tables show that this is affected much more strongly by field of education.

Table 1 reports new data on the proportion of undergraduates that private providers admit on the basis of a vocational qualification, and the proportion they admit from a low socioeconomic status background. The 32 private providers that admitted more than a handful of undergraduate students in 2008 are grouped into 8 creative arts colleges - such as JMC Academy (878 commencing bachelor students) and Qantm Pty Ltd (318); 10 private religious colleges, such as Avondale College (334) and Tabor College Adelaide (239); 5 private business colleges, such as Billy Blue (219) and the Melbourne Institute of Business and Technology (288); and 4 private health colleges, such as the Australian College of Natural Medicine $(1,465)$ and Nature Care College (184 commencing undergraduates). Finally, there is a group of 5 other private colleges, such as the Australian College of Physical Education (386) and the Australian Institute of Public Safety (135).

Private colleges admit a lower proportion of undergraduate students on the basis of a vocational qualification than do all university types, except the Group of Eight. Private colleges, broadly, do not admit a higher proportion of students from a low socioeconomic status background than public universities. This is very different from the US, where private for profit colleges admit a rather higher proportion of students from a low socioeconomic status background than public institutions (Lederman 2009). 
While TAFE institutes admit a higher proportion of students on the basis of vocational qualifications than do other institutions, they admit a lower proportion of students from a low socioeconomic status background than all other types of institutions, except for the Group of Eight universities and private art colleges.

Table 1 also shows the standard deviation and coefficient of variation in the proportion of undergraduates admitted on the basis of a vocational qualification, by institution type. This shows that there is considerable variation within the Group of Eight universities, since there is a reasonably high coefficient of variation. There is also considerable variation between religious and creative arts colleges. In contrast, the universities established in the 1960s-70s and the private business colleges seem reasonably homogeneous in the proportion of students they admit on the basis of a vocational qualification.

Table 1 Proportion of domestic bachelor students from a low socioeconomic status background and proportion admitted on the basis of a vocational qualification, by type of institution, 2008 (\%)

\begin{tabular}{|c|c|c|c|c|}
\hline \multirow[b]{2}{*}{ Institutional type } & \multirow{2}{*}{$\begin{array}{l}\% \text { of } \\
\text { low } \\
\text { SES }\end{array}$} & \multicolumn{3}{|c|}{ Basis of VET } \\
\hline & & $\begin{array}{l}\text { Mean } \\
(\%)\end{array}$ & $\begin{array}{l}\text { Standard } \\
\text { deviation }\end{array}$ & $\begin{array}{l}\text { Coefficient } \\
\text { of } \\
\text { variation }\end{array}$ \\
\hline ATN-like universities & 16 & 14 & 8 & 62 \\
\hline $\begin{array}{l}\text { New generation } \\
\text { universities }\end{array}$ & 16 & 13 & 7 & 54 \\
\hline 1960s-70s universities & 19 & 10 & 3 & 29 \\
\hline Rural universities & 26 & 9 & 6 & 66 \\
\hline $\begin{array}{l}\text { Group of Eight } \\
\text { universities }\end{array}$ & 11 & 2 & 2 & 106 \\
\hline All universities & 17 & 9 & 7 & 72 \\
\hline $\begin{array}{l}\text { Private creative arts } \\
\text { colleges }\end{array}$ & 10 & 5 & 8 & 167 \\
\hline Private religious colleges & 19 & 4 & 5 & 112 \\
\hline Private business colleges & 12 & 4 & 2 & 38 \\
\hline Private health colleges & 18 & 0 & 0 & 0 \\
\hline Other private colleges & 15 & 1 & 1 & 94 \\
\hline All private colleges & 14 & 3 & 5 & 169 \\
\hline All TAFE institutes & 12 & 19 & 13 & 88 \\
\hline All institutions & 17 & 9 & 7 & 72 \\
\hline
\end{tabular}

Source: Doherty (2009)

Of particular interest are the TAFE institutes that offer baccalaureates. Only 3 TAFE Institutes reported useable data on the basis of admission of their undergraduate students in 2008: Box Hill Institute of TAFE, the Gordon Institute of TAFE and Northern Melbourne Institute of TAFE. These reported small intakes in 2008, so they are considered together. TAFE institutes admitted a smaller proportion of their bachelor students on the basis of a higher education qualification than all higher education institutions, but higher proportions on the basis of vocational education and mature age qualifications. Even so, the TAFE institute that admitted 
the highest proportion of students on the basis of a vocational qualification admitted only $24 \%$ on this basis, less than Swinburne University (27\%) and equal to Victoria University (24\%). Charles Sturt University (22\%) and RMIT (21\%) also exceeded the TAFE average for proportion of students admitted on the basis of a vocational qualification.

Table 2 Proportion of domestic undergraduate students admitted by basis of admission, TAFE institutes and all higher education institutions, 2008 (\%)

\begin{tabular}{|c|c|c|c|c|c|c|}
\hline \multirow[b]{2}{*}{ Institute } & \multirow[b]{2}{*}{$\begin{array}{l}\text { Total } \\
\text { students }\end{array}$} & \multicolumn{5}{|c|}{ Basis of admission of commencing undergrads (\%) } \\
\hline & & Higher & Secondary & Vocational & $\begin{array}{l}\text { Mature } \\
\text { age }\end{array}$ & Other \\
\hline Box Hill TAFE & 187 & 4 & 67 & 19 & 9 & 1 \\
\hline NMIT & 76 & 3 & 28 & 24 & 32 & 12 \\
\hline Gordon Institute & 21 & 0 & 24 & 0 & 67 & 10 \\
\hline All TAFEs & 284 & 4 & 54 & 19 & 20 & 3 \\
\hline All Higher Ed & 206,939 & 23 & 45 & 9 & 6 & 17 \\
\hline
\end{tabular}

Source: Doherty (2009)

\section{Variations by field of education}

Table 3 shows variations by field of education. The analysis includes only fields with reasonable numbers of commencing students, thus excluding food, hospitality and personal services and mixed field programs, because they have low numbers of commencing students. As this paper explores in detail below, there are considerable variations in the proportions of students admitted on the basis of vocational qualifications in each field of education. This may reflect the numbers of vocational education graduates in each field. To test this, the paper first considers each field of education's share of undergraduates admitted on the basis of a vocational education.

Table 3 shows that management and commerce had the biggest share of undergraduates admitted on the basis of a vocational qualification (23\%) closely followed by society and culture - the humanities and social sciences—at 20\%. Management and commerce had the highest share (33\%) of vocational education enrolments in Certificate IV or higher. There seems to be a strong relation between a field of education's share of Certificate IV or higher vocational education enrolments and its share of students admitted on the basis of a vocational qualification. But there seems to be an even stronger relation between a field of education's share of students admitted on the basis of a vocational education qualification and its share of commencing bachelor students from a low socioeconomic status background. This suggests that while the 'push' factors from sending institutions are important in Australian upward student transfer, the 'pull' factors from receiving institutions are even more important for the proportion of students admitted on the basis of a vocational qualification. This confirms Australian analysts' concentration on receiving institutions. 
Table 3 Each broad field of education's share of enrolments in vocational education programs of Certificate IV or higher, share of domestic students admitted to a bachelor program on the basis of a vocational education qualification, and share of domestic low socioeconomic status backgrounds in higher education, 2008 (\%)

\begin{tabular}{lllll}
\hline Field of education & $\begin{array}{l}\text { \% cert IV } \\
\text { or higher } \\
\text { enrolments }\end{array}$ & $\begin{array}{l}\text { \% } \\
\text { admitted } \\
\text { to HEd on } \\
\text { VET } \\
\text { basis }\end{array}$ & $\begin{array}{l}\text { \% of HEd } \\
\text { commenc- } \\
\text { ements }\end{array}$ & $\begin{array}{l}\text { \% of HEd } \\
\text { low SES } \\
\text { commence- } \\
\text { ments }\end{array}$ \\
\hline Management and commerce & 33 & 23 & 17 & 15 \\
\hline Society and culture & 16 & 20 & 26 & 24 \\
\hline Health & 8 & 18 & 14 & 15 \\
\hline Education & 8 & 16 & 10 & 12 \\
\hline Creative arts & 6 & 8 & 9 & 8 \\
\hline Engineering and related technologies & 11 & 4 & 6 & 6 \\
\hline Information technology & 4 & 4 & 3 & 3 \\
\hline Natural and physical sciences & 1 & 3 & 8 & 9 \\
\hline Architecture and building & 5 & 3 & 3 & 2 \\
\hline Agriculture, environmental and related & 2 & 1 & 2 & 2 \\
\hline Food, hospitality and personal services & 2 & 0 & 0 & 0 \\
\hline Mixed field programs & 3 & 0 & 2 & 4 \\
\hline Total & $\mathbf{1 0 0}$ & $\mathbf{1 0 0}$ & $\mathbf{1 0 0}$ & $\mathbf{1 0 0}$ \\
\hline Correlation with admitted on VET basis & 0.79 & 1 & 0.89 & 0.89 \\
\hline
\end{tabular}

Sources: NCVER (2009) Table 1 Course field of education (major) by highest qualification level (current) for students created on 18 November 2009, and Doherty (2009)

Table 4 shows, for each higher education field of education, the proportion of commencing bachelor students admitted on the basis of a vocational qualification and the proportion of commencing bachelor students admitted from a low socioeconomic status background.

Nursing is shown separately, even though it is part of the health field of education, because it admits an unusually high proportion of students on the basis of a vocational qualification. Nursing admits almost 2.5 times the proportion of students on the basis of a vocational qualification than other fields, almost $70 \%$ higher than the next highest field, education. One possible reason is that nursing has an occupational progression from enrolled to registered nurse that is strongly aligned with progression from a vocational education Certificate IV or diploma of enrolled nursing (depending on the state) to a higher education bachelor of nursing. Nursing also admits the highest proportion of students from a low socioeconomic status background.

A low 3.5\% of students are admitted to baccalaureates in the natural and physical sciences on the basis of vocational education studies, and modest proportions of $8 \%$ or less are admitted into baccalaureates in engineering and related technologies, creative arts, society and culture and agriculture and related studies. There are likely to be different reasons for these low or modest proportions in each field. Table 4 shows that only $1 \%$ of publicly funded vocational education students are enrolled in the natural and physical sciences at Certificate IV level or higher (there are only $0.4 \%$ enrolled in the natural and physical sciences at all levels of vocational education [NCVER 2009] so there are relatively few students with a background in vocational education who may seek admission to higher education programs in the natural and physical sciences). In contrast, $11 \%$ of vocational education students in Certificate IV programs or higher are in engineering and related technologies, so the modest proportions of transfer students may owe more to higher education's entry prerequisites and the lack of part 
time programs in engineering (86\% of vocational education students are part time). The sectoral boundaries are less marked in the creative arts, so many students may achieve their goals in vocational education without having to proceed to higher education.

Table 4 Proportion of domestic students admitted to a bachelor program on the basis of a vocational education program, and proportion of students commencing a bachelor program from a low socioeconomic status background for each broad field of education in 2008 (\%)

\begin{tabular}{|c|c|c|}
\hline Field of education & $\begin{array}{l}\text { \% admitted to } \\
\text { HEd on VET } \\
\text { basis }\end{array}$ & $\begin{array}{l}\text { \% of HEd low } \\
\text { SES } \\
\text { commencements }\end{array}$ \\
\hline Nursing & 22 & 24 \\
\hline Education & 13 & 22 \\
\hline Information technology & 12 & 18 \\
\hline Management and commerce & 11.6 & 16 \\
\hline Health & 11 & 19 \\
\hline Architecture and building & 11 & 12 \\
\hline Agriculture, environmental and related studies & 8 & 21 \\
\hline Society and culture & 7 & 17 \\
\hline Creative arts & 7 & 14 \\
\hline Engineering and related technologies & 6 & 18 \\
\hline Natural and physical sciences & 3.5 & 17 \\
\hline All & 9 & 17 \\
\hline
\end{tabular}

Source: Doherty (2009)

There seems to be a relation between a field's proportion of students admitted on the basis of a vocational qualification and the proportion of its students from a low socioeconomic status background. This is because higher education institutions tend to admit higher proportions of students on the basis of a vocational education qualification when they have lower student demand, which results in a lower cut-off score. Student attainment in year 12 is strongly associated with socioeconomic status so that the lower scoring students admitted to programs with lower cut-off scores tend to come from low socioeconomic status backgrounds.

Table 5 considers the extent to which institutions vary in the proportion of students they admit on the basis of a vocational education qualification in each field of education. Table 4 reported the proportion of all domestic undergraduate students admitted on the basis of a vocational education qualification. Table 5 takes that proportion for each institution and then calculates an average or mean of the institutions' proportions. So while the proportion of all bachelor of nursing students admitted on the basis of a vocational qualification is $22 \%$, as reported in Table 4, the institutional mean for nursing reported in Table 5 is only $20 \%$. This suggests that there are several institutions which have small nursing intakes and admit a low proportion of students on the basis of a vocational qualification, depressing the institutional mean. This is consistent with Table 6 which lists several institutions with small nursing intakes that admit a low proportion of nursing students on the basis of a vocational qualification.

Table 5 shows that universities differ least in the proportion of bachelor of nursing students they admit on the basis of a vocational qualification. There is most variation between universities in architecture and building, creative arts, agriculture, environmental and related studies. This is probably because of the diversity of those fields of education. But there is more diversity in the proportions of students that universities admit on the basis of a vocational qualification in education and engineering, which are reasonably homogeneous fields with occupational registration requirements that are similar nationally. This may be 
because very few Group of Eight institutions, which admit unusually few students on the basis of a vocational qualification, offer nursing, but many offer education and engineering; this leads to higher variation in institutions' performance on vocational education transfers in education and engineering.

Table 5 Institutional means, standard deviations and variations of proportion of domestic bachelor students admitted on the basis of a vocational education qualification at Australian universities, 2008 (\%)

\begin{tabular}{llll}
\hline Field of education & $\begin{array}{l}\text { Institutional } \\
\text { mean (\%) }\end{array}$ & $\begin{array}{l}\text { Standard } \\
\text { deviation }\end{array}$ & $\begin{array}{l}\text { Coefficient of } \\
\text { variation }\end{array}$ \\
\hline Nursing & 20 & 14 & 67 \\
\hline Architecture and building & 13 & 20 & 154 \\
\hline Health & 12 & 11 & 95 \\
\hline Education & 11 & 10 & 91 \\
\hline Management and commerce & 11 & 9 & 84 \\
\hline Information technology & 10 & 10 & 96 \\
\hline Agriculture, environmental and related & 7 & 7 & 101 \\
\hline Society and culture & 7 & 7 & 98 \\
\hline Creative arts & 7 & 9 & 127 \\
\hline Engineering and related technologies & 6 & 6 & 99 \\
\hline Natural and physical sciences & 4 & 4 & 95 \\
\hline All & $\mathbf{9}$ & $\mathbf{7}$ & $\mathbf{7 2}$ \\
\hline
\end{tabular}

Source: Doherty (2009)

\section{Variations within nursing}

Finally, the paper examines the proportions of bachelor of nursing students admitted on the basis of a vocational qualification at each university, and the extent to which they differ from the treatment of other fields of education. The Australian Government has designated nursing, along with education, a national priority area, because state governments rely heavily on university graduates in nursing and teacher education to fill staffing needs for state responsibilities. Both occupations require a minimum period of placements in the workplace for graduates to be qualified to practice. Most placements are in state government hospitals or schools, yet universities have difficulty getting enough placements in state facilities to meet the need for qualified graduates in state facilities. Furthermore, state authorities charge universities sizeable fees for student placements, which are passed on to placement supervisors, most of whom are state employees. State governments have increased fees to supervise student placements, which in turn have been met by the Australian Government increasing funding to universities for student placements. So in effect, the Australian Government has met part of the cost of pay increases for nurses and teachers employed by state governments via increased payments for university students' placements. Universities' intakes into nursing (and education) programs are also limited by the number of suitably qualified applicants they attract. Accounts of relatively unrewarding working conditions, unemployed graduates, or more rewarding employment in other fields, depresses student demand for nursing programs.

While limits on student placements, cost pressures and limited student demand have affected most universities similarly, universities differ markedly in the ways they respond to those factors, and in particular, in the proportion of nursing students they admit on the basis of a vocational education qualification. The universities established from the mid 1960s to the mid 1970s admitted the highest proportion of bachelor of nursing students on the basis of a 
vocational education qualification (24\%). This is $10 \%$ more than the proportion of students that these universities admitted on the basis of a vocational qualification in all fields of education. Some universities, such as Wollongong and Murdoch universities, admitted over $40 \%$ of their bachelor of nursing students on the basis of a vocational qualification, around $30 \%$ more than the proportion of transfer students these universities admitted overall.

Other universities, such as Macquarie, Bond, Swinburne and most Group of Eight universities, don't offer nursing. The proportion of bachelor of nursing students admitted on the basis of vocational qualifications seems improbably low at the University of South Australia. The university reports that it admits an unusually high 30\% of bachelor of nursing students on the basis of occupational qualifications, and this may be enrolled nurses admitted to the bachelor of nursing on the basis of their nursing registration or on the basis of hospital qualifications.

In general it seems that universities admit a higher proportion of students on the basis of a vocational qualification in nursing than in other fields, and while this may be due partly to the lower selectivity of nursing programs, other factors are also important. The universities established in the 1960s and 70s admit a particularly high proportion of bachelor of nursing students on the basis of vocational qualifications, far more than the students they admit on the basis of vocational qualifications in other fields. The new generation and ATN-like universities admit a higher proportion of students on the basis of vocational qualifications overall than the 1960s-70s universities, but a lower proportion of nursing students on the basis of a vocational qualification.

Table 6 Proportion of domestic bachelor of nursing students admitted on the basis of a vocational qualification and proportion from a low socioeconomic status background, compared with all fields of education by Australian university, 2008 (\%)

\begin{tabular}{|c|c|c|c|c|c|c|}
\hline \multirow[b]{2}{*}{ University } & \multicolumn{3}{|c|}{ \% admitted on basis of VET } & \multicolumn{3}{|c|}{ \% low SES } \\
\hline & Nursing & $\begin{array}{l}\text { All } \\
\text { fields }\end{array}$ & $\begin{array}{l}\text { Difference } \\
\text { between } \\
\text { nursing } \\
\text { and all }\end{array}$ & Nursing & $\begin{array}{l}\text { All } \\
\text { fields }\end{array}$ & $\begin{array}{l}\text { Difference } \\
\text { between } \\
\text { nursing } \\
\text { and all }\end{array}$ \\
\hline Wollongong & 44 & 13 & 31 & 24 & 18 & 6 \\
\hline Murdoch University & 41 & 13 & 27 & 74 & 23 & 51 \\
\hline La Trobe University & 29 & 13 & 16 & 21 & 21 & 0 \\
\hline Deakin University & 24 & 13 & 11 & 17 & 15 & 2 \\
\hline Griffith University & 20 & 8 & 12 & 23 & 15 & 8 \\
\hline Flinders University & 10 & 8 & 2 & 26 & 23 & 3 \\
\hline Macquarie & 0 & 6 & 0 & 0 & 6 & 0 \\
\hline Mean of 60s-70s & 28 & 10 & 18 & 32 & 21 & 11 \\
\hline Victoria University & 46 & 24 & 22 & 28 & 27 & 1 \\
\hline ACU & 27 & 16 & 11 & 14 & 13 & 1 \\
\hline UWS & 27 & 16 & 11 & 17 & 16 & 1 \\
\hline Edith Cowan University & 19 & 12 & 7 & 12 & 15 & -3 \\
\hline Notre Dame Australia & 15 & 7 & 9 & 9 & 11 & -2 \\
\hline University of Canberra & 8 & 11 & -2 & 3 & 5 & -2 \\
\hline Bond University & 0 & 3 & 0 & 0 & 12 & 0 \\
\hline Mean of new gen & 24 & 13 & 11 & 14 & 15 & -1 \\
\hline UNE & 41 & 13 & 27 & 34 & 24 & 10 \\
\hline Charles Darwin & 39 & 13 & 26 & 23 & 13 & 10 \\
\hline
\end{tabular}




\begin{tabular}{|c|c|c|c|c|c|c|}
\hline \multirow[b]{2}{*}{ University } & \multicolumn{3}{|c|}{$\%$ admitted on basis of VET } & \multicolumn{3}{|c|}{$\%$ low SES } \\
\hline & Nursing & $\begin{array}{l}\text { All } \\
\text { fields }\end{array}$ & $\begin{array}{l}\text { Difference } \\
\text { between } \\
\text { nursing } \\
\text { and all } \\
\end{array}$ & Nursing & $\begin{array}{l}\text { All } \\
\text { fields }\end{array}$ & $\begin{array}{l}\text { Difference } \\
\text { between } \\
\text { nursing } \\
\text { and all } \\
\end{array}$ \\
\hline Charles Sturt University & 34 & 22 & 13 & 24 & 21 & 3 \\
\hline CQUni & 18 & 7 & 11 & 43 & 40 & 3 \\
\hline Southern Cross & 18 & 11 & 6 & 27 & 23 & 4 \\
\hline Southern Queensland & 17 & 8 & 9 & 28 & 29 & -1 \\
\hline James Cook University & 12 & 5 & 7 & 32 & 27 & 5 \\
\hline University of Ballarat & 12 & 8 & 4 & 23 & 21 & 2 \\
\hline Sunshine Coast & 8 & 4 & 4 & 12 & 14 & -2 \\
\hline University of Tasmania & 0 & 0 & 0 & 33 & 33 & 0 \\
\hline Mean of rural & 20 & 9 & 11 & 28 & 25 & 3 \\
\hline UTS & 33 & 12 & 21 & 8 & 9 & -1 \\
\hline RMIT & 26 & 21 & 5 & 23 & 18 & 5 \\
\hline Curtin University & 15 & 6 & 9 & 18 & 15 & 3 \\
\hline QUT & 14 & 7 & 7 & 16 & 13 & 3 \\
\hline UniSA & 7 & 9 & -2 & 41 & 28 & 13 \\
\hline Swinburne University & 0 & 27 & 0 & & 12 & 0 \\
\hline Mean of ATN-like & 19 & 14 & 5 & 22 & 17 & 5 \\
\hline Monash University & 2 & 7 & -5 & 27 & 14 & 13 \\
\hline University of Queensland & 2 & 2 & 0 & 26 & 16 & 10 \\
\hline ANU & 0 & 1 & 0 & 0 & 4 & 0 \\
\hline UNSW & 0 & 3 & 0 & 0 & 8 & 0 \\
\hline University of Adelaide & 0 & 1 & -1 & 23 & 17 & 6 \\
\hline University of Melbourne & 0 & 2 & 0 & 0 & 9 & 0 \\
\hline University of Sydney & 0 & 1 & -1 & 15 & 7 & 8 \\
\hline UWA & 0 & 0 & & 0 & 9 & 0 \\
\hline Mean of Go8 & 0 & 2 & -2 & 26 & 14 & 13 \\
\hline All universities & 22 & 9 & 13 & 24 & 17 & 7 \\
\hline
\end{tabular}

Source: Doherty (2009)

There is considerable variation in the proportions of nursing students that universities admit on the basis of vocational qualifications, even within university types. Some may be due to local circumstances; some is due to different institutional priorities and practices; some may be due to variations in data recording, collecting and reporting; and some may be due to different treatment of occupational and vocational qualifications. But it is also possible that these variations are due to other factors, which would warrant further investigation.

\section{Conclusion}

This study has followed the Australian tradition of considering upward student transfer from the perspective of receiving institutions. It found considerable variation in the proportion of domestic undergraduate students admitted on the basis of a vocational education qualification. Private colleges admit a relatively low proportion of students on the basis of vocational qualifications. While TAFE institutes admit the highest proportion of vocational students of 
any institutional type, some individual universities admitted a higher proportion of students on the basis of vocational qualifications than TAFE institutes.

There is also considerable variation by field of education. While some of this variation may be due to push factors, such as the number of vocational education graduates in each field, more of the variation seemed to be due to pull factors - the actions of higher education institutions. Nursing has the highest proportion of students admitted on the basis of vocational qualifications, and it seems that nursing is more homogeneous in this, than other fields.

Nonetheless, there remains considerable variation in the proportions of bachelor of nursing students admitted on the basis of vocational education qualifications. Much of this variation remains unexplained, and it would be worth examining whether the factors that have been found to affect student transfer overseas also apply in Australia. Hayward and colleagues (2004, p. 35) found that higher transfer rates from Californian community colleges to campuses of the California State University and the University of California were associated with community colleges being sizeable and relatively close to the university campus where they transfer their students, and to there being working partnerships between staff at selected community college and university campuses.

Many US States have been very active in promoting student transfer from 2-year to 4-year colleges. Wellman (2002) studied 6 US states that rely heavily on transfer from 2-year colleges to give low-income students access to the baccalaureate degree. Wellman characterised state policies influencing transfer from community to baccalaureate colleges as either structural or academic. Structural polices are those that affect the overall approach to postsecondary education: governance, institutional and sector mission and differentiation, statewide information system capacity, funding, planning capacities and accountability mechanisms. Wellman argues that the preconditions of student transfer are determined by these structural policies and by demography, economic conditions and institutional histories. Wellman understands academic policies to be those specific to transfer from 2- to 4-year institutions. They are designed to influence the internal alignment of students, programs and subjects within and across institutions. Academic policies concern admission standards, curriculum requirements, articulation and transfer of credit. Wellman found that the key difference between the 3 high-performing states and the others in her study seems to lie in the statewide governance structure for higher education. The low-performing states construct transfer as mainly an academic and institutional matter and grant institutions considerable autonomy, while the high-performing states have a comprehensive, integrated approach to transfer implemented by stronger state governance or coordinating mechanisms.

Wellman also found that all 3 of the high-performing states also use data better to improve transfer performance, including reporting to campuses about their performance relative to others. This echoes Rifkin's (1998, p. 6) finding that: 'Effective transfer programs benefit from a well developed technical infrastructure that includes statewide student information and tracking systems, articulation databases and research on transfer. The most effective programs have all three and often are found in states where higher education is closely coordinated at the state agency level.' It therefore seems that no single measure is likely to increase the proportion of bachelor students admitted on the basis of a vocational qualification, either within each field of education or within each type of institution, let alone for all fields in all institutions.

The Australian Government (Commonwealth of Australia 2009, p. 43) has said that 'It should be straight forward (sic) for students to enter post-school education and move between vocational and higher education as appropriate to enhance their skills and qualifications' but has neither elaborated a mechanism nor set a target for what it would consider to be a desirable 
rate at which students move between vocational and higher education. An obvious indicator of students' rate of movement between the sectors is the student transfer rate, and an implication of the government's statement is that the current transfer rate should be increased. It is not possible to calculate transfer rates directly, because of limitations of the data collected by the National Centre for Vocational Education Research, the Department of Education, Employment and Workplace Relations and the Australian Bureau of Statistics. However, it is possible to analyse data on the proportion of undergraduates admitted on the basis of a vocational education qualification, and this study has found marked differences in these rates that have no apparent explanation.

There seem to be 2 options for governments seeking to increase the proportion of bachelor students admitted on the basis of vocational qualifications. One would be to seek measures specific to each field of education. This is the approach the Australian Government is taking to higher education quality assurance. It commissioned the Australian Learning and Teaching Council (Sachs, Mansfield and Kosman 2011) to develop academic standards for each level of qualification in each discipline. A second option would be to introduce incentives for institutions to increase the proportion of students they admit on the basis of vocational qualifications and leave institutions to develop their own policies and strategies. This is the approach the Australian Government is taking to encourage institutions to admit higher proportions of students from low socioeconomic status backgrounds. From January 2010 the Australian Government has given institutions a loading of $2 \%$ on the amount it pays for each equivalent full time student for students from a low socioeconomic status background, and increased this to 3\% in 2011 and 4\% in 2012 (Commonwealth of Australia 2009, p. 13). Whichever approach were to be adopted would be more effective than the current strategy, which seems to be to state general policy goals unsupported either by detailed strategies or a general incentive.

\section{Acknowledgements}

An earlier version of this paper was presented to the Australian Vocational Education and Training Research Association's 13th annual conference at Surfers Paradise on 8-9 April, 2010. The AER's two referees provided valuable comments on the initial manuscript.

\section{References}

Bathmaker, A., Brooks, G., Parry, G. \& Smith, D. (2008). Dual-sector further and higher education: policies, organisations and students in transition. Research Papers in Education, 23(2), 125-137.

Bradley, D. (chair). (2008). Review of Australian higher education Final report. Canberra: Commonwealth of Australia. www.deewr.gov.au/he_review_finalreport. Accessed 23 December 2008.

Carlan, P. \& Byxbe, F. R. (2000). Community colleges under the microscope: an analysis of performance predictors for native and transfer students. Community College Review, 28(i2), 27.

Commonwealth of Australia. (2009). Transforming Australia's higher education system. Commonwealth of Australia.

http://home.deewr.gov.au/Budget/documents/TransformingAusHigherED.pdf. Accessed 12 May 2009. 
Crump, S. (2007). Changing identities and performance of post-compulsory educational providers. The Australian Educational Researcher, 34(3), 1-14.

Curtis, D. (2006). Inter-sectoral transfers: sense, status, prevalence and purpose. Paper presented at the 15th national vocational education and training research conference: 15 th, 12 14 July, Mooloolaba, Australia.

http://www.voced.edu.au/docs/confs/ncver/vetconf15/tr15curtis.pdf. Accessed 23 September 2008.

Dougherty, K. J. (1992). Community colleges and baccalaureate attainment. The Journal of Higher Education, 63(2), 188-214.

Doherty, L. (2009). Extract from Students, selected higher education statistics (DEST) RFI: 09-219 produced 6 August 2009.

Gallacher, J. (2003). Higher education in further education colleges: the Scottish experience. London: Council for Industry and Higher Education. http://www.ciheuk.com/docs/PUBS/0303HEinFECScottish.pdf. Accessed 19 March 2003.

Garrod, N. \& Macfarlane, B. (Eds.) (2009). Challenging boundaries: managing the integration of post-secondary education. New York: Routledge.

Gelin, F. (1999). Transfer rates: how to measure and for what purpose? A discussion paper. Vancouver: British Columbia Council on Admissions and Transfer. http://www.bccat.bc.ca/pubs/transrates.pdf. Accessed 21 January 2010.

Hall, P. A. \& Soskice, D. (2001). An introduction to varieties of capitalism. In P. A. Hall \& D. Soskice (Eds.) Varieties of capitalism: the institutional foundations of comparative advantage (pp. 1-68). Oxford: Oxford University Press.

Hayward, G. C., Jones, D. P., McGuinness, A. C. Jr. \& Timar, A. (2004). Ensuring access with quality to California's community colleges, report \#04-3. San Jose, California: National Center for Public Policy and Higher Education.

http://www.highereducation.org/reports/hewlett/Hewlett3.pdf. Accessed 23 December 2007.

Higher Education Funding Council for England (Hefce). (2006). Higher education in further education colleges: consultation on HEFCE policy. Bristol: Hefce.

http://www.hefce.ac.uk/pubs/hefce/2006/06_48/. Accessed 23 November 2006.

Higher Education Funding Council for England (Hefce). (2007). Pathways to higher education: BTEC courses. Bristol: Hefce. http://www.hefce.ac.uk/pubs/hefce/2007/07_35/. Accessed 21 January 2010.

Hoelscher, M., Hayward, G., Ertl, H. \& Dunbar-Goddet, H. (2008). The transition from vocational education and training to higher education: a successful pathway? Research Papers in Education, 23(2), 139-151.

Lederman, D. (2009). Served, yes, but well-served? Inside Higher Ed, 8 October. http://www.insidehighered.com/news/2009/10/08/pell. Accessed 22 January 2010.

Moodie, G. (2005). Student transfers. Adelaide: National Centre for Vocational Education Research. 
Moodie, G. (2007). Do tiers affect student transfer? Examining the student admission ratio. Community College Journal of Research \& Practice, 31(11), 847-861.

Moodie, G. (2008). From vocational to higher education: an international perspective. Maidenhead: McGraw-Hill.

National Centre for Vocational Education Research (NCVER). (2009). Students and courses 2008, Students by courses. Adelaide: NCVER.

http://www.ncver.edu.au/statistic/publications/2164.html. Accessed 18 November 2009.

Parry, G. (2003). Mass higher education and the English: wherein the colleges? Higher Education Quarterly, 57(4), 308-337.

Rifkin, T. (1998). Improving articulation policy to increase transfer. ECS policy paper, Denver: Education Commission of the States.

http://www.eric.ed.gov/ERICDocs/data/ericdocs2sql/content_storage_01/0000019b/80/16/24/c f.pdf. Accessed 23 December 2007.

Sachs, J., Mansfield, N. and Kosman, B. (2011). Teaching standards framework project. Final report. Australian Learning and Teaching Council. http://www.olt.gov.au/resources. Accessed 16 February 2012.

Shaw, K. M. \& London, H. B. (2001). Culture and ideology in keeping transfer commitment: three community colleges. The Review of Higher Education, 25(1), 91-114.

Smith, C. T. \& Miller, A. with Bermeo, C. A. (2009). Bridging the gaps to success: promising practices promoting transfer among low income and first generation students, an in depth study of six exemplary community colleges in Texas. Washington: Pell Institute. http://www.pellinstitute.org/pdf/COE_Pell_Report_layout_3.pdf. Accessed 20 January 2009.

Striplin, J. J. (1999). Facilitating transfer for first-generation community college students. ERIC Digest. Los Angeles, California: ERIC Clearinghouse for Community Colleges. (ERIC Reproduction Service Document No. ED 430627.

http://www.eric.ed.gov/ERICWebPortal/custom/portlets/recordDetails/detailmini.jsp?_nfpb=tr ue\&_\&ERICExtSearch_SearchValue_0=ED430627\&ERICExtSearch_SearchType_0=no\&acc no=ED430627. Accessed 21 January 2010.

Stevenson, J. (2007). Technical and Further Education reforms: theoretical issues. The Australian Educational Researcher, 34(3), 15-34.

Wassmer, R., Moore, C. \& Shulock, N. (2003). A quantitative study of California community college transfer rates: policy implications and a future research agenda. Sacramento: Senate Office of Research. http://www.csus.edu/ihelp/PDFs/SOR\%20paper-

COMMUNITYCOLLEGETRANSFER.pdf. Accessed 20 January 2009.

Wellman, J. V. (2002). State policy and community college-baccalaureate transfer, National Center Report \#02-6. The National Centre for Public Policy and Higher Education.

http://www.highereducation.org/reports/transfer/transfer.shtml. Accessed 23 December 2007.

Wheelahan, L. (2009). Do educational pathways contribute to equity in tertiary education in Australia? Critical Studies in Education, 50(3), 261-275. 
Wheelahan, L. \& Moodie, G. (2005). Separate post-compulsory education sectors within a liberal market economy: interesting models generated by the Australian anomaly. In M. Osborne \& J. Gallacher (Eds.) A contested landscape. International perspectives on diversity in mass higher education (pp. 18-46). Leicester: National Institute of Adult Continuing Education.

White, M. (2009). Keeping VET and higher education in perspective. Campus Review, 27 April. http://www.campusreview.com.au/pages/section/article.php?s=VET\&idArticle=7081. Accessed 27 April 2009. 